\title{
Angiotensin-(1-7) Changes Apoptosis-Related Genes Expression in Human Breast Cancer Cell Line T47D
}

\author{
Cheryl Alecrim Santos ${ }^{1}$, Gabriela Soares da Silva Brito ${ }^{1}$, \\ Silvana Aparecida Alves Corrêa de Noronha ${ }^{2}$, Samuel Marcos Ribeiro de Noronha ${ }^{2}$, \\ Suma Imura Shimuta ${ }^{3}$, Clovis Ryiuchi Nakaie ${ }^{3}$, Ismael Dale Cotrim Guerreiro da Silva ${ }^{1}$ \\ ${ }^{1}$ Department of Gynecology, Federal University of Sao Paulo, Sao Paulo, Brazil \\ ${ }^{2}$ Department of Surgery, Federal University of Sao Paulo, Sao Paulo, Brazil \\ ${ }^{3}$ Department of Biophysics, Federal University of Sao Paulo, São Paulo, Brazil \\ Email: cheryl.ale@hotmail.com
}

Received 21 September 2014; revised 18 October 2014; accepted 15 November 2014

Academic Editor: Yu Cao, The Scripps Research Institute, USA

Copyright (C) 2014 by authors and Scientific Research Publishing Inc.

This work is licensed under the Creative Commons Attribution International License (CC BY).

http://creativecommons.org/licenses/by/4.0/

(c) (†) Open Access

\begin{abstract}
Angiotensin-(1-7) [Ang-(1-7)] is a heptapeptide of the renin-angiotensin system with vasodilator and anti-proliferative properties. In the present study, we aim to investigate whether Ang-(1-7) induces apoptosis in breast cancer cells and whether the altered expression of apoptosis-related genes is involved in this process. Human breast cell line T47D was treated with angiotensin-(1-7) and angiotensin II (Ang II). Cell proliferation and apoptosis were quantified using hemocytometer and flow cytometry, respectively. The expression of 84 apoptosis-related genes was evaluated through qPCR array. Ang-(1-7), as opposed to Ang II, decreased proliferation and increased apoptosis in T47D cells. Moreover, many pro-apoptotic genes were up-regulated, such as $B A K 1, B A X$, $B C L 2 L 1, B I D$ and $B I K$. In addition, some anti-apoptotic genes as $A K T 1$ and XIAP were down-regulated by heptapeptide. Although a deeper study should be performed, our results support the hypothesis that Ang-(1-7) could change the expression of several genes related to apoptosis, interfering directly in the molecular pathways associated with the survival of breast cancer cells.
\end{abstract}

\section{Keywords}

Angiotensin-(1-7), Breast Cancer Cells, Apoptosis, qPCR Array 


\section{Introduction}

Breast cancer is the most common cancer in women and the second leading cause of cancer death in women worldwide [1] [2]. It is a multifactorial disease caused by epigenetic changes and genetic mutations that occur in genes directly involved in the process of cell division and programmed cell death [3]-[5]. Therefore, studies on chemotherapy agents and their mechanisms of action are particularly relevant.

Studies have shown that the components of the renin-angiotensin system (RAS) act in the carcinogenic process [6]-[8]. Angiotensin II (Ang II), considered the main effector of the RAS, has vasoconstrictive, angiogenic and proliferative properties [9]-[12]. Angiotensin-(1-7) [Ang-(1-7)] is an endogenous 7-amino acid peptide hormone of the RAS that has vasodilator, anti-proliferative and anti-angiogenic actions [13]-[17]. Thus, Ang-(1-7) opposes the action of Ang II.

The relationship between genetic polymorphisms of the Angiotensin II, Angiotensin-(1-7) and AngiotensinConverting Enzyme (ACE) with breast cancer was demonstrated in many works [18]-[21]. In vitro assays show that Ang-(1-7) inhibits the proliferation of lung cancer cells [22]. Ang-(1-7) treatment decreased microvessel density associated with a reduction in both vascular endothelial growth factor and placental growth factor in lung and breast tumor xenograft [23] [24]. It has also been demonstrated that Ang-(1-7) inhibits tumoral fibrosis [25] and attenuates multilineage cytopenias following chemotherapy [26]. All these results suggest that heptapeptide might be a general regulator of cell growth, suggesting its potential use as a promising antitumor agent.

Programmed cell death (apoptosis) is considered an innate defense mechanism leading the cell to become antineoplastic; similarly, many chemotherapeutic agents act by inducing this type of cell death [27]. Therefore, we aim to investigate whether Ang-(1-7) induces apoptosis in breast cancer cells and whether the altered expression of apoptosis-related genes is involved in this process.

\section{Materials and Methods}

\subsection{Cell Culture and Treatments}

The human ductal breast epithelial tumor cell line T47D was originally obtained from ATCC (American Type Culture Collection). T47D cells was grown in DMEM supplemented with 10\% FBS, 100 UI/mL penicillin, 100 ug/mL streptomycin (all from Invitrogen), 2 UI/mL human insulin, and $4 \mathrm{mM}$ glutamine (both from SigmaAldrich). The control group was treated with DMEM supplemented only. The experimental groups were treated with DMEM supplemented and peptides: Ang II and Ang-(1-7) in the concentration of $10^{-6} \mathrm{M}$. The peptides were replaced daily due to their rapid degradation [28].

\subsection{Cell Proliferation Assay}

T47D cells were seeded into 24-well plates $\left(1 \times 10^{3}\right.$ cells/well). After $2,6,9$, and 15 days the cells were removed from triplicate wells using trypsin/EDTA and counted using a hemocytometer.

\subsection{Apoptosis Assay}

T47D cells were seeded into 24-well plates. After 2, 6, 9, and 15 days of treatment the cells were removed from triplicate wells using trypsin/EDTA. Posteriorly, cells were stained with Annexin V using the Guava Nexin kit (Millipore) according to the manufacturer's instructions. The cells from each well were resuspended in $100 \mu$ of supplemented DMEM $\left(1 \times 10^{5}\right.$ cells/well $)$ and $100 \mu \mathrm{l}$ of the Guava Nexin Reagent. Samples were incubated in the dark at room temperature for $20 \mathrm{~min}$ and subsequently evaluated in the Guava easyCyte ${ }^{\mathrm{TM}}$ cytometer (Millipore).

\subsection{RNA Extraction}

Total RNA was extracted from T47D cells (treated with peptides for 48 hours) using the TRIzol reagent (Invitrogen), according to the manufacturer's instructions, and subjected to DNase treatment using an RNase-free DNase kit (Qiagen). The quantity and quality of extracted RNA were measured by spectrophotometer (NanoDrop Technologies).

\section{5. qPCR Array}

The Human Apoptosis RT2 Profiler PCR Array (SA Bioscience) was used to simultaneously evaluate the ex- 
pression profile of 84 key genes involved in programmed cell death.

Total RNA $(2 \mu \mathrm{g})$ was converted to cDNA via reverse transcriptase reaction using the First Strand Kit (SABiosciences), according to the manufacturer's instructions. This kit includes a proprietary buffer that eliminates residual genomic DNA contamination in cell line RNA samples. A reaction mix containing cDNA and all the optimized reagents and buffers needed for $\mathrm{SYBR}^{\circledR}$ Green were prepared based upon real-time polymerase chain reactions. Twenty-five microliters of this mix was added to each well of the 96-well plate, which was then loaded out on a 7500 Fast Real-Time PCR System (Applied Biosystems) and run in a two-step cycling program with one initial cycle of $10 \mathrm{~min}$ at $95^{\circ} \mathrm{C}$ and 40 cycles of $15 \mathrm{~s}$ at $95^{\circ} \mathrm{C}$, and one final cycle of $1 \mathrm{~min}$ at $60^{\circ} \mathrm{C}$, in a 7500 Fast Real-Time PCR System (Applied Biosystems).

\subsection{Statistical Analysis}

Cell proliferation and apoptosis assays were analyzed by descriptive statistics (means and standard deviation) and inferential statistics through the Student's $t$-test with significance level of $5 \%(\mathrm{p}<0.05)$. qPCR Array reactions were analyzed trough the RT2 Profiler ${ }^{\mathrm{TM}}$ PCR Array Data Analysis software (SABiosciences). We only considered p values below 0.05 and fold regulation values higher than 2.00 to be statistically significant.

\section{Results}

\subsection{Cell Proliferation Analysis}

Ang-(1-7) decreases the proliferation of T47D cells, while Ang II increased the proliferation of these cells (Figure 1). Ang (1-7) had opposite effects to Ang II.

\subsection{Apoptosis Analysis}

Ang-(1-7) increased apoptosis in T47D cells after 6, 9 and 15 days (Figure 2). The apoptotic effect on breast cancer cells was similar in all treatment periods (except 2 days) After 2 days of treatment we observed a high percentage of apoptotic cells, but there were no significant differences between groups.

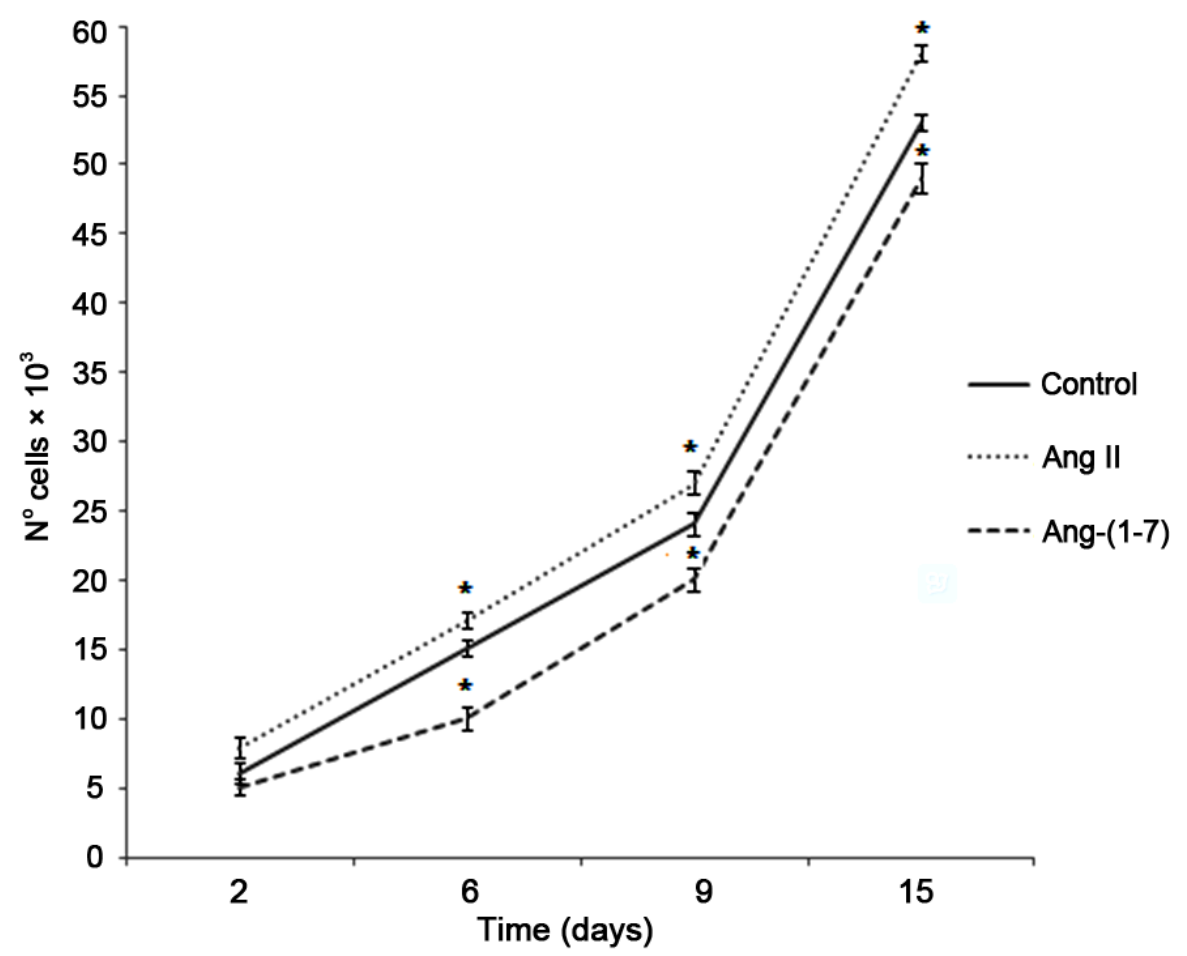

Figure 1. Proliferation of T47D cells after treatment with Ang-(1-7) and Ang II. ${ }^{*} \mathrm{p}<0.05$ (compared to control). 


\section{3. qPCR Array Analysis}

The qPCR Array assay was performed to determine the expression profiles of 84 apoptosis-related genes. Ang(1-7) altered the expression of 60 genes compared to the control group; 47 were up-regulated and 13 were downregulated, whereas Ang II altered the expression of 22 genes; 7 were up-regulated and 15 were down-regulated (Table 1).

Some anti-apoptotic genes were down-regulated due Ang-(1-7) treatment (Figure 3). In contrast, several genes involved in the induction of apoptosis were up-regulated by heptapeptide (Figure 4). Most of the times, Ang II had opposite effects to Ang-(1-7).

\section{Discussion}

In the present study we investigated the pro-apoptotic effects of the Ang-(1-7) in human ductal breast epithelial tumor cell line T47D. This line was selected specially for display luminal phenotype with positive expression of estrogen and progesterone, thus constitutes an experimental model which represents approximately $75 \%$ of cases of breast cancer diagnosed in clinical practice.

Our results show that Ang-(1-7) hormone has anti-proliferative and pro-apoptotic actions on T47D breast cancer cells. A similar effect was evidenced in studies with human prostate malignant cells [29] and human lung cancer cells [22] [24].

Ang-(1-7) inhibited the proliferation of T47D breast cancer cells, whereas Ang II favored the proliferation of these cells. Other studies conducted in mammary cells showed similar results [30]-[32]. Our findings therefore further confirm that Ang-(1-7) and Ang II often have opposing biological actions.

Analysis of apoptosis by flow cytometry showed that Ang-(1-7) is able to induce apoptosis in breast tumor cell line, but does not cause this effect in normal mammary epithelial cell line MCF-10A. In addition, the qPCR assay performed in T47D cells demonstrated that the Ang-(1-7) might change the expression of more than 70\% of apoptosis-related genes (55.9\% genes were up-regulated and 15.5\% were down-regulated). On the other hand, Ang II changed the expression of $26 \%$ of apoptosis-related genes (8.3\% genes up-regulated and $17.9 \%$ genes down-regulated).

Apoptosis is induced via two main routes involving either the mitochondria (the intrinsic pathway) or the activation of death receptors (the extrinsic pathway). The intrinsic pathway is induced by various types of intracellular stress and is mediated by members of the $B C L-2$ family. The extrinsic signaling pathway involves the activation of transmembrane death receptors that are members of the TNF superfamily. Both pathways converge to induce the activation of initiator and executioner caspases, leading in programmed cell death [33] [34].

The expression of caspases 1, 2, 4, 5, 7, 9, 10 and 14 was increased after treatment with Ang-(1-7). The association of these caspases with apoptosis has been described in several studies [35]-[41].

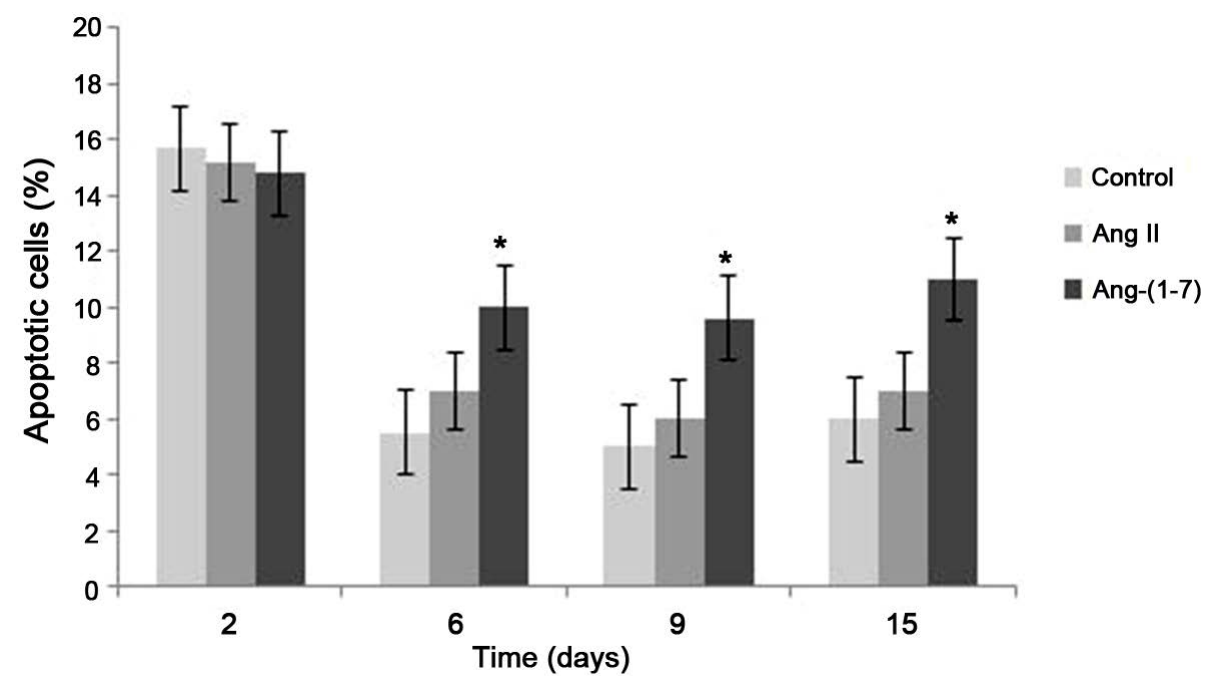

Figure 2. Apoptosis percentage of T47D cells after treatment with Ang-(1-7) and Ang II. * $\mathrm{p}<$ 0.05 (compared to control). 
Table 1. Apoptosis-related genes expression profile in human breast cancer cells after Ang-(1-7) and Ang II treatment.

\begin{tabular}{|c|c|c|c|c|c|}
\hline Gene & Fold change & Fold change & Gene & Fold change & Fold change \\
\hline Symbol & Ang-(1-7) $\times \mathrm{CT}$ & Ang-II $\times$ CT & Symbol & Ang-(1-7) $\times \mathrm{CT}$ & Ang II $\times$ CT \\
\hline ABL1 & 14.5827 & 0.8335 & CASP7 & 3.5602 & 0.831 \\
\hline AKT1 & 0.4335 & 0.422 & CASP8 & 0.5605 & 0.8348 \\
\hline APAF1 & 1.2685 & 0.836 & CASP9 & 3.8289 & 1.6668 \\
\hline BAD & 1.6643 & 0.8292 & CD40 & 2.9917 & 2.0927 \\
\hline BAG1 & 1.2078 & 0.8423 & CD40LG & 9.5977 & 0.8327 \\
\hline BAG3 & 0.8741 & 0.8415 & CFLAR & 5.4723 & 1.7056 \\
\hline BAG4 & 0.2102 & 0.8399 & CIDEA & 9.5977 & 3.5808 \\
\hline BAK1 & 2.604 & 1.6774 & CIDEB & 1.4202 & 0.4142 \\
\hline BAX & 9.3295 & 0.4154 & CRADD & 0.9825 & 1.6924 \\
\hline BCL10 & 0.1657 & 1.6664 & DAPK1 & 9.5977 & 0.8327 \\
\hline BCL2 & 14.7275 & 1.6287 & DFFA & 0.1422 & 0.8319 \\
\hline BCL2A1 & 0.2139 & 1.6847 & FADD & 0.4021 & 0.4185 \\
\hline BCL2L1 & 10.5406 & 0.4134 & FAS & 0.3109 & 0.4174 \\
\hline BCL2L10 & 9.5977 & 0.8493 & FASLG & 9.5977 & 0.8327 \\
\hline BCL2L11 & 0.8152 & 1.6665 & GADD45A & 2.2975 & 0.4233 \\
\hline BCL2L2 & 1.1388 & 1.6713 & HRK & 0.9564 & 1.6665 \\
\hline BCLAF1 & 0.1145 & 1.6424 & IGF1R & 1.4168 & 3.3446 \\
\hline BFAR & 0.1481 & 1.6861 & LTA & 9.5977 & 0.8879 \\
\hline BID & 2.2737 & 0.8362 & LTBR & 9.4426 & 0.8435 \\
\hline BIK & 4.5455 & 1.3173 & MCL1 & 10.1351 & 3.3414 \\
\hline NAIP & 2.345 & 0.8453 & NOL3 & 0.7898 & 1.6754 \\
\hline BIRC2 & 0.8614 & 1.6483 & PYCARD & 3.2496 & 0.8455 \\
\hline BIRC3 & 0.8803 & 0.8456 & RIPK2 & 3.0304 & 1.6477 \\
\hline XIAP & 0.2851 & 0.8333 & TNF & 19.5397 & 3.3521 \\
\hline BIRC6 & 2.862 & 1.69 & TNFRSF10A & 0.9505 & 0.2116 \\
\hline BIRC8 & 9.5977 & 3.5536 & TNFRSF10B & 0.6384 & 0.8365 \\
\hline BNIP1 & 0.3422 & 0.8315 & TNFRSF11B & 9.5977 & 0.8327 \\
\hline BNIP2 & 3.2399 & 0.8434 & TNFRSF1A & 5.4577 & 1.6898 \\
\hline BNIP3 & 0.6969 & 1.6738 & TNFRSF21 & 1.0109 & 0.8427 \\
\hline BNIP3L & 1.8115 & 1.6647 & TNFRSF25 & 1.1189 & 0.4218 \\
\hline BRAF & 2.5251 & 1.6606 & CD27 & 9.048 & 1.0456 \\
\hline NOD1 & 2.4816 & 1.6586 & TNFRSF9 & 9.5977 & 0.8708 \\
\hline CARD6 & 1.115 & 0.4216 & TNFSF10 & 5.1556 & 0.8337 \\
\hline CARD8 & 0.5609 & 1.0618 & CD70 & 9.5977 & 2.8259 \\
\hline CASP1 & 2.3419 & 1.6759 & TNFSF8 & 9.5977 & 0.8327 \\
\hline CASP10 & 9.5977 & 0.8582 & TP53 & 0.2649 & 0.6586 \\
\hline CASP14 & 8.9969 & 0.7806 & ТР53ВР2 & 0.1871 & 0.8422 \\
\hline CASP2 & 7.9715 & 0.4181 & TP73 & 2.2379 & 1.6741 \\
\hline CASP3 & 1.1176 & 1.6624 & TRADD & 2.2328 & 0.8334 \\
\hline CASP4 & 5.3219 & 0.4193 & TRAF2 & 3.0765 & 0.42 \\
\hline CASP5 & 9.5977 & 0.8327 & TRAF3 & 7.3658 & 0.8305 \\
\hline CASP6 & 1.7785 & 0.4178 & TRAF4 & 3.6426 & 0.2059 \\
\hline
\end{tabular}

Fold-change and fold-regulation values greater than 2 are indicated in red, fold-change values smaller than 0.05 , and fold-regulation values smaller than -2 are indicated in blue. 


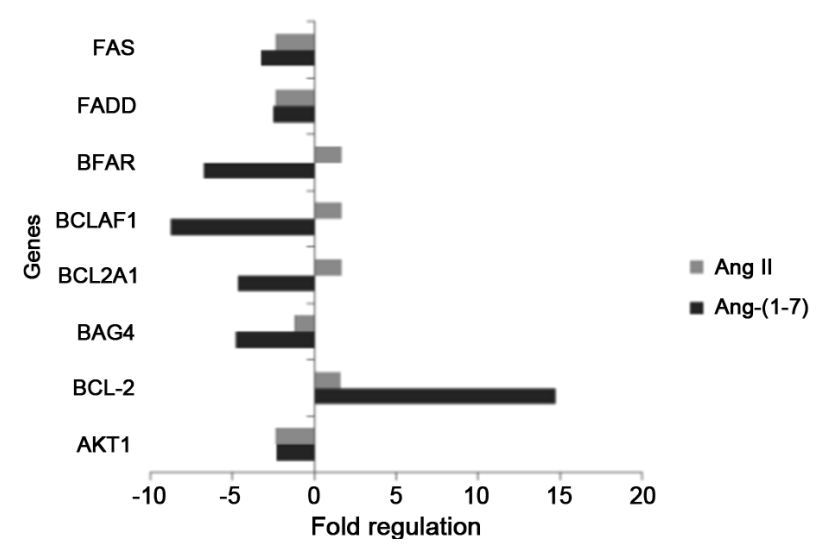

Figure 3. Anti-apoptotic genes with altered expression after Ang-(1-7) and Ang II treatment. T47D cells were treated for 48 hours with the peptides and gene expression was verified by qPCR. Fold-regulation values greater than 2 indicate up-regulation and fold-regulation values smaller than -2 indicate down-regulation.

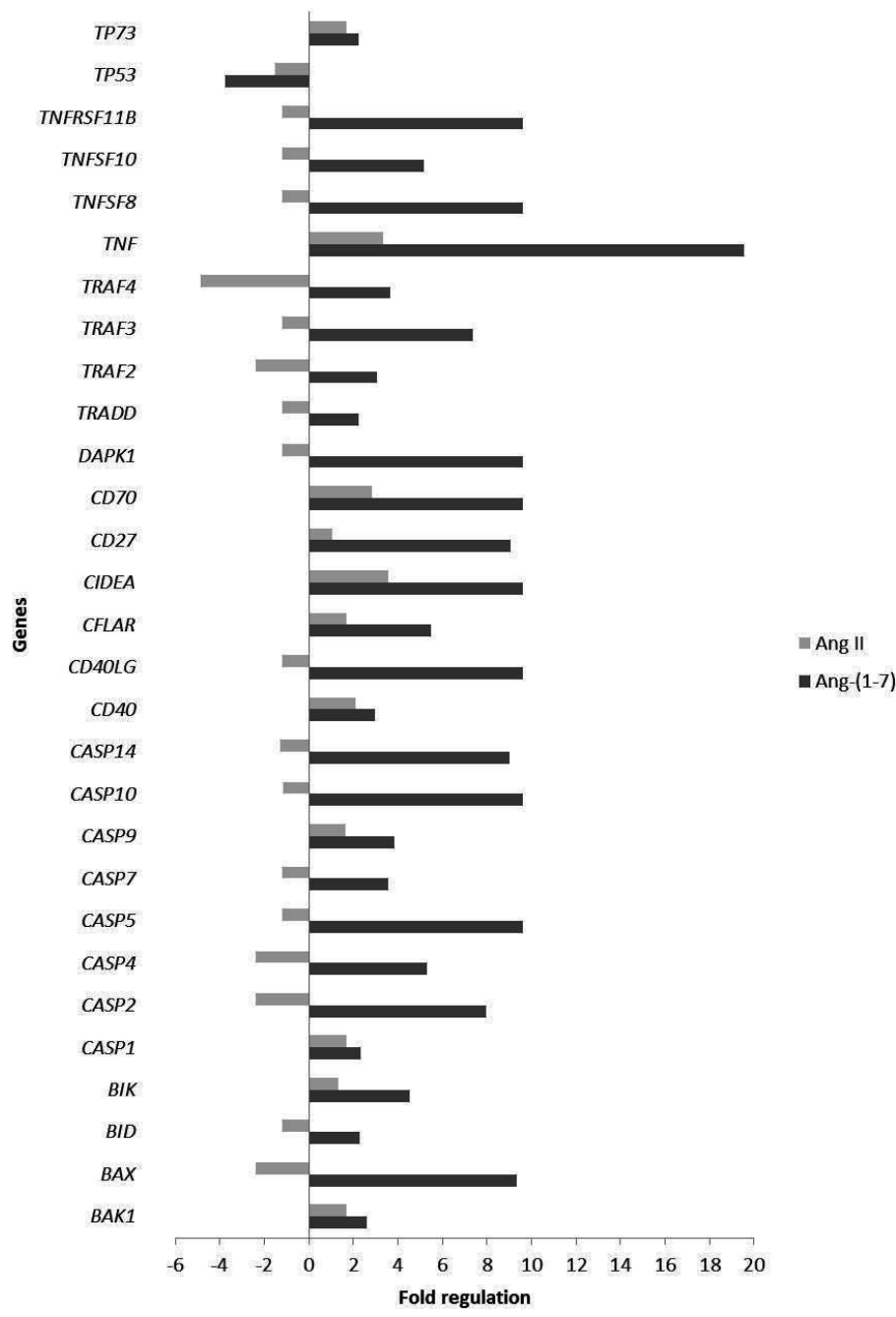

Figure 4. Pro-apoptotic genes with altered expression after Ang-(1-7) and Ang II treatment. T47D cells were treated for 48 hours with the peptides and gene expression was verified by qPCR. Fold-regulation values greater than 2 indicate up-regulation and fold-regulation values smaller than -2 indicate down-regulation. 
Pro-apoptotic genes of the $B C L-2$ family, such as $B A X, B I D, B I K$ and $B A K$, were up-regulated after treatment with Ang-(1-7). The induction of apoptosis by these genes has been fully demonstrated in several studies [42][44].

Estrogen-dependent cancers, such as breast and endometrial cancer, exhibit high expression of the $B C L-2$ gene (anti-apoptotic) and possibly for this reason, have low level of apoptosis [45]-[47]. In this, the BCL-2 gene was overexpressed by Ang-(1-7), but the apoptotic percentage of T47D cells was significantly greater when compared to the control group. We infer if the increased expression of the $B A X$ gene (pro-apoptotic), which was up-regulated after treatment with Ang-(1-7), might have antagonized the protective effect of $B C L-2$. This effect has been shown in some studies with the $B A K$ gene (which functions similar to the $B A X$ ). The overexpression of this gene induces apoptosis in cancer cells even in the presence of high expression levels of anti-apoptotic genes of the Bcl-2 family [48] [49].

BIK has the capacity to induce apoptosis in mammary adenocarcinoma cells [50] and sensitize tumor cells to chemotherapeutic agents [51]. This corroborates with the findings of our study and opens the possibility of the use of Ang-(1-7) as a chemotherapy sensitizer.

The genes of the TNF superfamily, including TNF, TNFSF10, TNFSF8 and TNFRSF11B, encode apoptotic proteins [52] [53]. These genes were overexpressed by Ang-(1-7).

Ang-(1-7) induced the expression of $C D 40$ and $C D 40 L$ genes. Studies conducted in pancreatic cancer cell lines demonstrated that the expression of these genes have growth inhibitory effect [54]-[56].

CFLAR, CIDEA, DAPK1, FASLG, CD27 and CD70 genes induce cell death [57]-[60]. TRADD, TRAF2, TRAF3 and TRAF4 are genes that encode proteins that increase apoptosis rate [61] [62]. All these genes were up-regulated after treatment with Ang-(1-7) in the present study.

The TP53 gene, encoding the p53 protein, is mutated in line T47D and perhaps for this reason was not observed increased expression of this gene suppressor tumor after treatment with the Ang-(1-7). However, there was a significant increase in expression of TP73, encoding a protein of very similar role to TP53. The TP73 gene is capable of acting on $B A X, B C L 2 L 1, M C L$ and Caspase 9 [63], inducing apoptosis in tumor cells.

In this study, some genes considered anti-apoptotic or apoptosis suppressing, such as $A K T 1, B A G 4, B C L 2 A 1$, BCLAF1, BFAR, FADD, FAS and XIAP [64]-[72] were down-regulated by Ang-(1-7).

The $A K T 1$ gene encodes the Protein Kinase $\mathrm{B}$, which is capable of inhibiting the protein BAD through phosphorylation and induce anti-apoptotic effects [73].

The XIAP gene protects endometrium carcinoma cells against various pro-apoptotic agents [74] [75]. The use of RNA interference (siRNA) against XIAP induces apoptosis and inhibits potential tumor growth in breast cancer cells [76].

In summary, apoptosis was increased and the expression of several genes related to apoptosis was changed after Ang-(1-7) treatment.

\section{Conclusion}

Our results support the hypothesis that Ang-(1-7) could change the expression of several apoptosis-related genes, interfering directly in the molecular pathways associated with the survival of breast cancer cells. In vivo assays are being conducted to confirm the potential of this hormone as an antitumor agent.

\section{Acknowledgements}

The work was supported by grants number 2008/54383-0, 2010/03658-9 and 2011/08531-0 from the Sao Paulo Research Foundation (FAPESP)-Brazil.

\section{References}

[1] Jemal, A., Siegel, R., Ward, E., Hao, Y., Xu, J., Murray, T. and Thun, M.J. (2008) Cancer Statistics: 2008. CA: A Cancer Journal for Clinicians, 58, 71-96. http://dx.doi.org/10.3322/CA.2007.0010

[2] American Cancer Society (2014) Cancer Facts \& Figures 2014. American Cancer Society, Atlanta.

[3] Daidone, M.G., Paradiso, A., Gion, M., Harbeck, S.F. and Schmitt, M. (2004) Biomolecular Features of Clinical Relevance in Breast Cancer. European Journal of Nuclear Medicine and Molecular Imaging, 31, 3-14. http://dx.doi.org/10.1007/s00259-004-1522-0 
[4] Lopez-Garcia, M.A., Geyer, F.C., Lacroix-Triki, M., Marchió, C. and Reis-Filho, J.S. (2010) Breast Cancer Precursors Revisited: Molecular Features and Progression Pathways. Histopathology, 57, 171-192.

http://dx.doi.org/10.1111/j.1365-2559.2010.03568.x

[5] Weinberg, R.A. (2008) A biologia do câncer. Artmed, Porto Alegre, 728 p.

[6] Ager, E.I., Neo, J. and Christophi, C. (2008) The Renin-Angiotensin System and Malignancy. Carcinogenesis, 29, 1675-1684. http://dx.doi.org/10.1093/carcin/bgn171

[7] Deshayes, F. and Nahmias, C. (2005) Angiotensin Receptors: A New Role in Cancer? Trends in Endocrinology and Metabolism, 16, 293-299. http://dx.doi.org/10.1016/j.tem.2005.07.009

[8] Okamoto, K., Tajima, H., Ohta, T., Nakanuma, S., Hayashi, H., Nakagawara, H., et al. (2010) The Role of Renin-Angiotensin System Independent Angiotensin II Production in Progression and Fibrosis of Intrahepatic Cholangiocarcinoma. Journal of Cancer and Chemotherapy, 37, 2231-2233.

[9] Baker, K.M. and Aceto, J.F. (1990) Angiotensin II Stimulation of Protein Syntheses and Cell Growth in Chick Heart Cells. American Journal of Physiology-Heart and Circulatory Physiology, 259, H610-H618.

[10] Weber, H., Taylor, D.S. and Molloy, C.I. (1994) Angiotensin II Induces Delayed Mitogenesis and Cellular Proliferation in Rat Aortic Smooth Muscle. Journal of Clinical Investigation, 93, 788-798. http://dx.doi.org/10.1172/JCI117033

[11] Andrade, S.P., Cardoso, C.C., Machado, R.D.P. and Beraldo, W.T. (1996) Angiotensin-II-Induced Angiogenesis Is Sponge Implant in Mice. International Journal of Microcirculation, 16, 302-307. http://dx.doi.org/10.1159/000179189

[12] Parenti, A., Brogelli, L., Donnini, S., Ziche, M. and Ledda, F. (2001) Ang II Potentiates Mitogenic Effect of Norepinephrine in Vascular Muscle Cells: Role of FGF-2. American Journal of Physiology: Heart and Circulatory Physiology, 280, H99-H107.

[13] Santos, R.A., Campagnole-Santos, M.J. and Andrade, S.P. (2000) Angiotensin-(1-7): An Update. Regulatory Peptides, 91, 45-62. http://dx.doi.org/10.1016/S0167-0115(00)00138-5

[14] Strawn, W.B., Ferrario, C.M. and Tallant, E.A. (1999) Angiotensin (1-7) Reduces Smooth Muscle Growth after Vascular Injury. Hypertension, 33, 207-211. http://dx.doi.org/10.1161/01.HYP.33.1.207

[15] Freeman, E.J., Chisolm, G.M., Ferrario, C.M. and Tallant, E.A. (1996) Angiotensin-(1-7) Inhibits Vascular Smooth Muscle Cell Growth. Hypertension, 28, 104-108. http://dx.doi.org/10.1161/01.HYP.28.1.104

[16] Tallant, E.A., Ferrario, C.M. and Gallagher, P.E. (2005) Angiotensin-(1-7) Inhibits Growth of Cardiac Myocytes through Activation of the Mas Receptor. American Journal of Physiology: Heart and Circulatory Physiology, 289, H1560-H1566. http://dx.doi.org/10.1152/ajpheart.00941.2004

[17] Machado, R.D., Santos, R.A. and Andrade, S.P. (2000) Opposing Actions of Angiotensins on Angiogenesis. Life Sciences, 66, 67-76. http://dx.doi.org/10.1016/S0024-3205(99)00562-7

[18] Alves Corrêa, S.A., Ribeiro de Noronha, S.M., Nogueira-de-Souza, N.C., Valleta de Carvalho, C., Massad Costa, A.M., et al. (2009) Association between the Angiotensin Converting Enzyme (Insertion/Deletion) and Angiotensin II Type 1 Receptor (A1166C) Polymorphisms and Breast Cancer among Brazilian Women. Journal of Renin-Angiotensin-Aldosterone System, 10, 51-58. http://dx.doi.org/10.1177/1470320309102317

[19] Mendizábal-Ruiz, A.P., Morales, J.A., Castro Martinez, X., Rubio, S.A.G., Valdez, L., Vásquez-Camacho, J.G., et al. (2011) RAS Polymorphisms in Cancerous and Benign Breast Tissue. Journal of Renin-Angiotensin-Aldosterone System, 12, 85-92. http://dx.doi.org/10.1177/1470320310383735

[20] Namazi, S., Monabati, A., Ardeshir-Rouhani-Fard, S. and Azarpira, N. (2010) Association of Angiotensin I Converting Enzyme (Insertion/Deletion) and Angiotensin II Type 1 Receptor (A1166C) Polymorphisms with Breast Cancer Prognostic Factors in Iranian Population. Molecular Carcinogenesis, 49, 1022-1030. http://dx.doi.org/10.1002/mc.20685

[21] Correa-Noronha, S.A.A., Noronha, S.M.R., Alecrim, C., Mesquita, A.C., Brito, G.S.S., Junqueira, M.G., et al. (2012) Association of Angiotensin-Converting Enzyme I Gene I/D Polymorphism with Endometrial but Not with Ovarian Cancer. Gynecological Endocrinology, 28, 889-891. http://dx.doi.org/10.3109/09513590.2012.683060

[22] Gallagher, P.E. and Tallant, E.A. (2004) Inhibition of Human Lung Cancer Cell Growth by Angiotensin-(1-7). Carcinogenesis, 25, 2045-2052. http://dx.doi.org/10.1093/carcin/bgh236

[23] Soto-Pantoja, D.R., Menon, J., Gallagher, P.E. and Tallant, E.A. (2009) Angiotensin-(1-7) Inhibits Tumor Angiogenesis in Human Lung Cancer Xenografts with a Reduction in Vascular Endothelial Growth Factor. Molecular Cancer Therapeutics, 8, 1676-1683. http://dx.doi.org/10.1158/1535-7163.MCT-09-0161

[24] Menon, J., Soto-Pantoja, D.R., Callahan, M.F., Cline, J.M., Ferrario, C.M., Tallant, E.A. and Gallagher, P.E. (2007) Angiotensin-(1-7) Inhibits Growth of Human Lung Adenocarcinoma Xenografts in Nude Mice through a Reduction in Cyclooxygenase-2. Cancer Research, 67, 2809-2815. http://dx.doi.org/10.1158/0008-5472.CAN-06-3614

[25] Cook, K.L., Metheny-Barlow, L.J., Tallant, E.A. and Gallagher, P.E. (2010) Angiotensin-(1-7) Reduces Fibrosis in 
Orthotopic Breast Tumors. Cancer Research, 70, 8319-8328. http://dx.doi.org/10.1158/0008-5472.CAN-10-1136

[26] Rodgers, K.E., Oliver, J. and di Zerega, G.S. (2006) Phase I/II Dose Escalation Study of Angiotensin 1-7 [A(1-7)] Administered before and after Chemotherapy in Patients with Newly Diagnosed Breast Cancer. Cancer Chemotherapy and Pharmacology, 57, 559-568. http://dx.doi.org/10.1007/s00280-005-0078-4

[27] Nicholson, D.W. (2000) From Bench to Clinic with Apoptosis-Based Therapeutic Agents. Nature, 407, 810-816. http://dx.doi.org/10.1038/35037747

[28] Chappell, M.C., Pirro, N.T., Sykes, A. and Ferrario, C.M. (1998) Metabolism of Angiotensin-(1-7) by AngiotensinConverting Enzyme. Hypertension, 31, 362-367. http://dx.doi.org/10.1161/01.HYP.31.1.362

[29] Krishnan, B., Smith, T.L., Dubey, P., Zapadka, M.E., Torti, F.M., Willingham, M.C., Tallant, E.A. and Gallagher, P.E. (2012) Angiotensin-(1-7) Attenuates Metastatic Prostate Cancer and Reduces Osteoclastogenesis. The Prostate, 73, 7182.

[30] Muscella, A., Greco, S., Elia, M.G., Storelli, C. and Marsigliante, S. (2002) Angiotensin II Stimulation of Na ${ }^{+} / \mathrm{K}^{+} \mathrm{ATPase}$ Activity and Cell Growth by Calcium-Independent Pathway in MCF-7 Breast Cancer Cells. Journal of Endocrinology, 173, 315-323. http://dx.doi.org/10.1677/joe.0.1730315

[31] Zivadinovic, D., Gametchu, B. and Watson, C.S. (2005) Membrane Estrogen Receptor-Alpha Levels in MCF-7 Breast Cancer Cells Predict cAMP and Proliferation Responses. Breast Cancer Research, 7, R101-R112. http://dx.doi.org/10.1186/bcr958

[32] Greco, S., Muscella, A., Elia, M.G., Salvatore, P., Storelli, C., Mazzotta, A., et al. (2003) Angiotensin II Activates Extracellular Signal Regulated Kinases via Protein Kinase C and Epidermal Growth Factor Receptor in Breast Cancer Cells. Journal of Cellular Physiology, 196, 370-377. http://dx.doi.org/10.1002/jcp.10313

[33] Green, D.R. (2000) Apoptotic Pathways: Paper Wraps Stone Blunts Scissors. Cell, 102, 1-4. http://dx.doi.org/10.1016/S0092-8674(00)00003-9

[34] Bras, M., Queenan, B. and Susin, S.A. (2005) Programmed Cell Death via Mitochondria: Different Modes of Dying. Biochemistry, 70, 231-239.

[35] Fushimi, K., Ray, P., Kar, A., Wang, L., Sutherland, L.C. and Wu, J.Y. (2008) Up-Regulation of the Proapoptotic Caspase 2 Splicing Isoform by a Candidate Tumor Suppressor, RBM5. Proceedings of the National Academy of Sciences of the United States of America, 105, 15708-15713. http://dx.doi.org/10.1073/pnas.0805569105

[36] Yamamuro, A., Kishino, T., Ohshima, Y., Yoshioka, Y., Kimura, T., Kasai, A. and Maeda, S. (2011) Caspase-4 Directly Activates Caspase-9 in Endoplasmic Reticulum Stress-Induced Apoptosis in SH-SY5Y Cells. Journal of Pharmacological Sciences, 115, 239-243. http://dx.doi.org/10.1254/jphs.10217SC

[37] Jiang, H., Zhang, L., Liu, J., Chen, Z., Na, R., Ding, G., et al. (2012) Knockdown of Zinc Finger Protein X-Linked Inhibits Prostate Cancer Cell Proliferation and Induces Apoptosis by Activating Caspase-3 and Caspase-9. Cancer Gene Therapy, 19, 684-689. http://dx.doi.org/10.1038/cgt.2012.53

[38] Li, C., Harada, A. and Oh, Y. (2012) IGFBP-3 Sensitizes Antiestrogen-Resistant Breast Cancer Cells through Interaction with GRP78. Cancer Letters, 325, 200-206. http://dx.doi.org/10.1016/j.canlet.2012.07.004

[39] Manzl, C., Peintner, L., Krumschnabel, G., Bock, F., Labi, V., Drach, M., et al. (2012) PIDDosome-Independent Tumor Suppression by Caspase-2. Cell Death \& Differentiation, 19, 1722-1732. http://dx.doi.org/10.1038/cdd.2012.54

[40] Nohara, K., Yokoyama, Y. and Kano, K. (2007) The Important Role of Caspase-10 in Sodium Butyrate-Induced Apoptosis. Kobe Journal of Medical Sciences, 53, 265-273.

[41] Ren, K., Lu, J., Porollo, A. and Du, C. (2012) Tumor-Suppressing Function of Caspase-2 Requires Catalytic Site Cys-320 and Site Ser-139 in Mice. Journal of Biological Chemistry, 287, 14792-14802. http://dx.doi.org/10.1074/jbc.M112.347625

[42] Azmi, A.S. and Mohammad, R.M. (2009) Non-Peptidic Small Molecule Inhibitors against Bcl-2 for Cancer Therapy. Journal of Cellular Physiology, 218, 13-21. http://dx.doi.org/10.1002/jcp.21567

[43] Sung, E.S., Park, K.J., Choi, H.J., Kim, C.H. and Kim, Y.S. (2012) The Proteasome Inhibitor MG132 Potentiates TRAIL Receptor Agonist-Induced Apoptosis by Stabilizing tBid and Bik in Human Head and Neck Squamous Cell Carcinoma Cells. Experimental Cell Research, 318, 1564-1576. http://dx.doi.org/10.1016/j.yexcr.2012.04.003

[44] Zhang, W., Wang, X. and Chen, T. (2012) Resveratrol Induces Apoptosis via a Bak-Mediated Intrinsic Pathway in Human Lung Adenocarcinoma Cells. Cell Signal, 24, 1037-1046. http://dx.doi.org/10.1016/j.cellsig.2011.12.025

[45] Lipponen, P., Pietiläinen, T., Kosma, V.M., Aaltomaa, S., Eskelinen, M. and Syrjäunen, K. (1995) Apoptosis Suppressing Protein Bcl-2 Is Expressed in Well-Differentiated Breast Carcinomas with Favorable Prognosis. The Journal of Pathology, 177, 49-55. http://dx.doi.org/10.1002/path.1711770109

[46] Saegusa, M., Kamata, Y., Isono, M. and Okayasu, I. (1996) Bcl-2 Expression Is Correlated with a Low Apoptotic Index and Associated with Progesterone Receptor Immunoreactivity in Endometrial Carcinomas. The Journal of Pathol- 
ogy, 180, 275-282. http://dx.doi.org/10.1002/(SICI)1096-9896(199611)180:3<275::AID-PATH660>3.0.CO;2-A

[47] Mustonen, M., Raunio, H., Paakko, P. and Soini, Y. (1997) The Extent of Apoptosis Is Inversely Associated with Bcl-2 Expression in Premalignant and Malignant Breast Lesions. Histopathology, 31, 347-354. http://dx.doi.org/10.1046/j.1365-2559.1997.2710877.x

[48] Holinger, E.P., Chittenden, T. and Lutz, R.J. (1999) Bak $\mathrm{BH}_{3}$ Peptides Antagonize Bcl- $\mathrm{x}_{\mathrm{L}}$ Function and Induce Apoptosis through Cytochrome c-Independent Activation of Caspases. Journal of Biological Chemistry, 274, 13298-13304. http://dx.doi.org/10.1074/jbc.274.19.13298

[49] Pataer, A., Fang, B., Yu, R., Kagawa, S., Hunt, K.K., McDonnell, T.J., et al. (2000) Adenoviral Bak Overexpression Mediates Caspase-Dependent Tumor Killing. Cancer Research, 60, 788-792.

[50] Hur, J., Chesnes, J., Coser, K.R., Lee, R.S., Geck, P., Isselbacher, K.J., et al. (2004) The Bik BH ${ }_{3}$-Only Protein Is Induced in Estrogen-Starved and Antiestrogen-Exposed Breast Cancer Cells and Provokes Apoptosis. Proceedings of the National Academy of Sciences of the United States of America, 10, 2351-2356. http://dx.doi.org/10.1073/pnas.0307337101

[51] Daniel, P.T., Pun, K.T., Ritschel, S., Sturm, I., Holler, J., Dörken, B., et al. (1999) Expression of the Death Gene Bik/Nbk Promotes Sensitivity to Drug-Induced Apoptosis in Corticosteroid-Resistant T-Cell Lymphoma and Prevents Tumor Growth in Severe Combined Immunodeficient Mice. Blood, 94, 1100-1107.

[52] Matsumoto, K., Terakawa, M., Miura, K., Fukuda, S., Nakajima, T. and Saito, H. (2004) Extremely Rapid and Intense Induction of Apoptosis in Human Eosinophils by Anti-CD30 Antibody Treatment in Vitro. The Journal of Immunology, 172, 2186-2193. http://dx.doi.org/10.4049/jimmunol.172.4.2186

[53] Liu, Y., Wang, L., Lin, X.Y., Wang, J., Yu, J.H., Miao, Y. and Wang, E.H. (2012) Anti-Apoptotic Effect of Claudin-1 on TNF- $\alpha$-Induced Apoptosis in Human Breast Cancer MCF-7 Cells. Tumor Biology, 33, 2307-2315.

[54] Elmetwali, T., Young, L.S. and Palmer, D.H. (2010) CD40 Ligand-Induced Carcinoma Cell Death: A Balance between Activation of TNFR-Associated Factor (TRAF) 3-Dependent Death Signals and Suppression of TRAF6-Dependent Survival Signals. Journal of Immunology, 184, 1111-1120. http://dx.doi.org/10.4049/jimmunol.0900528

[55] He, S., Zhao, H., Fei, M., Wu, Y., Wang, L., Zhu, X. and Li, D. (2012) Expression of the Co-Signaling Molecules CD40-CD40L and Their Growth Inhibitory Effect on Pancreatic Cancer in Vitro. Oncology Reports, 28, 262-268.

[56] Jundi, M., Nadiri, A., Al-Zoobi, L., Hassan, G.S. and Mourad, W. (2012) CD40-Mediated Cell Death Requires TRAF6 Recruitment. Immunobiology, 217, 375-383. http://dx.doi.org/10.1016/j.imbio.2011.07.007

[57] Aulwurm, S., Wischhusen, J., Friese, M., Borst, J. and Weller, M. (2006) Immune Stimulatory Effects of CD70 Override CD70-Mediated Immune Cell Apoptosis in Rodent Glioma Models and Confer Long-Lasting Antiglioma Immunity in Vivo. International Journal of Cancer, 118, 1728-1735. http://dx.doi.org/10.1002/ijc.21544

[58] von Rossum, A., Krall, R., Escalante, N.K. and Choy, J.C. (2011) Inflammatory Cytokines Determine the Susceptibility of Human CD8 T Cells to Fas-Mediated Activation-Induced Cell Death through Modulation of FasL and c-FLIPs Expression. Journal of Biological Chemistry, 286, 21137-21144. http://dx.doi.org/10.1074/jbc.M110.197657

[59] Li, F., Gu, Y., Dong, W., Li, H., Zhang, L., Li, N., et al. (2010) Cell Death-Inducing DFF45-like Effector, a Lipid Droplet-Associated Protein, Might Be Involved in the Differentiation of Human Adipocytes. FEBS Journal, 277, 41734183. http://dx.doi.org/10.1111/j.1742-4658.2010.07806.X

[60] Yoo, H.J., Byun, H.J., Kim, B.R., Lee, K.H., Park, S.Y. and Rho, S.B. (2012) DAPk1 Inhibits NF- $\kappa$ B Activation through TNF- $\alpha$ and INF- $\gamma$-Induced Apoptosis. Cell Signal, 24, 1471-1477. http://dx.doi.org/10.1016/j.cellsig.2012.03.010

[61] Georgopoulos, N.T., Steele, L.P., Thomson, M.J., Selby, P.J., Southgate, J. and Trejdosiewicz, L.K. (2006) A Novel Mechanism of CD40-Induced Apoptosis of Carcinoma Cells Involving TRAF3 and JNK/AP-1 Activation. Cell Death and Differentiation, 13, 1789-1801. http://dx.doi.org/10.1038/sj.cdd.4401859

[62] He, B.L., Yuan, J.M., Yang, L.Y., Xie, J.F., Weng, S.P., Yu, X.Q. and He, J.G. (2012) The Viral TRAF Protein (ORF111L) from Infectious Spleen and Kidney Necrosis Virus Interacts with TRADD and Induces Caspase 8-Mediated Apoptosis. PLoS ONE, 7, e37001. http://dx.doi.org/10.1371/journal.pone.0037001

[63] Somasagara, R.R., Hegde, M., Chiruvella, K.K., Musini, A., Choudhary, B., et al. (2012) Extracts of Strawberry Fruits Induce Intrinsic Pathway of Apoptosis in Breast Cancer Cells and Inhibits Tumor Progression in Mice. PLoS ONE, 7, e47021. http://dx.doi.org/10.1371/journal.pone.0047021

[64] Vázquez-Franco, J.E., Reyes-Maldonado, E., Vela-Ojeda, J., Domínguez-López, M.L. and Lezama, R.A. (2012) Src, Akt, NF- $\kappa$ B, BCL-2 and c-IAP 1 May Be Involved in an Anti-Apoptotic Effect in Patients with BCR-ABL Positive and BCR-ABL Negative Acute Lymphoblastic Leukemia. Leukemia Research, 36, 862-867. http://dx.doi.org/10.1016/j.leukres.2012.03.020

[65] Annunziata, C.M., Kleinberg, L., Davidson, B., Berner, A., Gius, D., Tchabo, N., et al. (2007) BAG-4/SODD and Associated Antiapoptotic Proteins Are Linked to Aggressiveness of Epithelial Ovarian Cancer. Clinical Cancer Research, 
13, 6585-6592. http://dx.doi.org/10.1158/1078-0432.CCR-07-0327

[66] McPherson, J.P., Sarras, H., Lemmers, B., Tamblyn, L., Migon, E., Matysiak-Zablocki, E., et al. (2009) Essential Role for Bclaf1 in Lung Development and Immune System Function. Cell Death and Differentiation, 16, 331-339. http://dx.doi.org/10.1038/cdd.2008.167

[67] Fan, G., Simmons, M.J., Ge, S., Dutta-Simmons, J., Kucharczak, J., et al. (2010) Defective Ubiquitin-Mediated Degradation of Antiapoptotic Bfl-1 Predisposes to Lymphoma. Blood, 115, 3559-3569. http://dx.doi.org/10.1182/blood-2009-08-236760

[68] Roth, W., Kermer, P., Krajewska, M., Welsh, K., Davis, S., Krajewski, S. and Reed, J.C. (2003) Bifunctional Apoptosis Inhibitor (BAR) Protects Neurons from Diverse Cell Death Pathways. Cell Death and Differentiation, 10, 11781187. http://dx.doi.org/10.1038/sj.cdd.4401287

[69] Yuan, K., Jing, G., Chen, J., Liu, H., Zhang, K., Li, Y., et al. (2011) Calmodulin Mediates Fas-Induced FADD-Independent Survival Signaling in Pancreatic Cancer Cells via Activation of Src-Extracellular Signal-Regulated Kinase (ERK). The Journal of Biological Chemistry, 286, 24776-24784. http://dx.doi.org/10.1074/jbc.M110.202804

[70] Wensveen, F.M., Unger, P.P., Kragten, N.A., Derks, I.A., ten Brinke, A., Arens, R., et al. (2012) CD70-Driven Costimulation Induces Survival or Fas-Mediated Apoptosis of T Cells Depending on Antigenic Load. Journal of Immunology, 188, 4256-4267. http://dx.doi.org/10.4049/jimmunol.1102889

[71] Holcik, M., Gibson, H. and Korneluk, R.G. (2001) XIAP: Apoptotic Brake and Promising Therapeutic Target. Apoptosis, 6, 253-261. http://dx.doi.org/10.1023/A:1011379307472

[72] Kunze, D., Wuttig, D., Fuessel, S., Kraemer, K., Kotzsch, M., Meye, A., et al. (2008) Multitarget siRNA Inhibition of Antiapoptotic Genes (XIAP, BCL 2 , BCL-XL) in Bladder Cancer Cells. Anticancer Research, 28, 2259-2264.

[73] Datta, S.R., Dudek, H., Tao, X., Masters, S., Fu, H., Gotoh, Y., et al. (1997) Akt Phosphorylation of BAD Couples Survival Signals to the Cell-Intrinsic Death Machinery. Cell, 9, 231-241. http://dx.doi.org/10.1016/S0092-8674(00)80405-5

[74] Gagnon, V., Van Themsche, C., Turner, S., Leblanc, V. and Asselin, E. (2008) Akt and XIAP Regulate the Sensitivity of Human Uterine Cancer Cells to Cisplatin, Doxorubicin and Taxol. Apoptosis, 13, 259-271. http://dx.doi.org/10.1007/s10495-007-0165-6

[75] Van Themsche, C., Lafontaine, L. and Asselin, E. (2008) X-Linked Inhibitor of Apoptosis Protein Levels and Protein Kinase C Activity Regulate the Sensitivity of Human Endometrial Carcinoma Cells to Tumor Necrosis Factor AlphaInduced Apoptosis. Endocrinology, 149, 3789-3798. http://dx.doi.org/10.1210/en.2008-0275

[76] Zhang, Y., Wang, Y., Gao, W., Zhang, R., Han, X., Jia, M. and Guan, W. (2006) Transfer of siRNA against XIAP Induces Apoptosis and Reduces Tumor Cells Growth Potential in Human Breast Cancer in Vitro and in Vivo. Breast Cancer Research and Treatment, 96, 267-277. http://dx.doi.org/10.1007/s10549-005-9080-0

\section{List of Abbreviations Used}

ACE: Angiotensin-Converting Enzyme;

Ang II: Angiotensin II;

Ang-(1-7): Angiotensin-(1-7);

cDNA: Complementary DNA;

DMEM: Dulbecco's Modified Eagle Medium;

FBS: Fetal Bovine Serum;

PCR: Polymerase Chain Reaction;

qPCR: Real-Time PCR or Quantitative PCR;

RNA: Ribonucleic Acid;

RAS: Renin-Angiotensin System. 
Scientific Research Publishing (SCIRP) is one of the largest Open Access journal publishers. It is currently publishing more than 200 open access, online, peer-reviewed journals covering a wide range of academic disciplines. SCIRP serves the worldwide academic communities and contributes to the progress and application of science with its publication.

Other selected journals from SCIRP are listed as below. Submit your manuscript to us via either submit@scirp.org or Online Submission Portal.
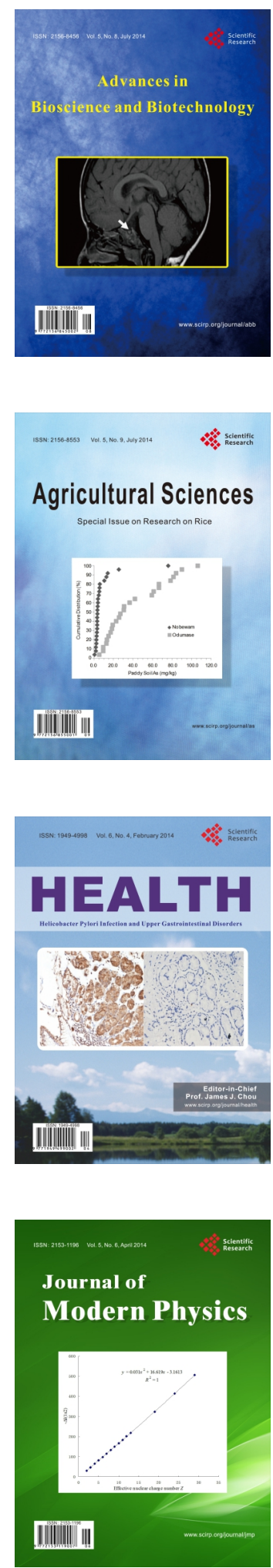
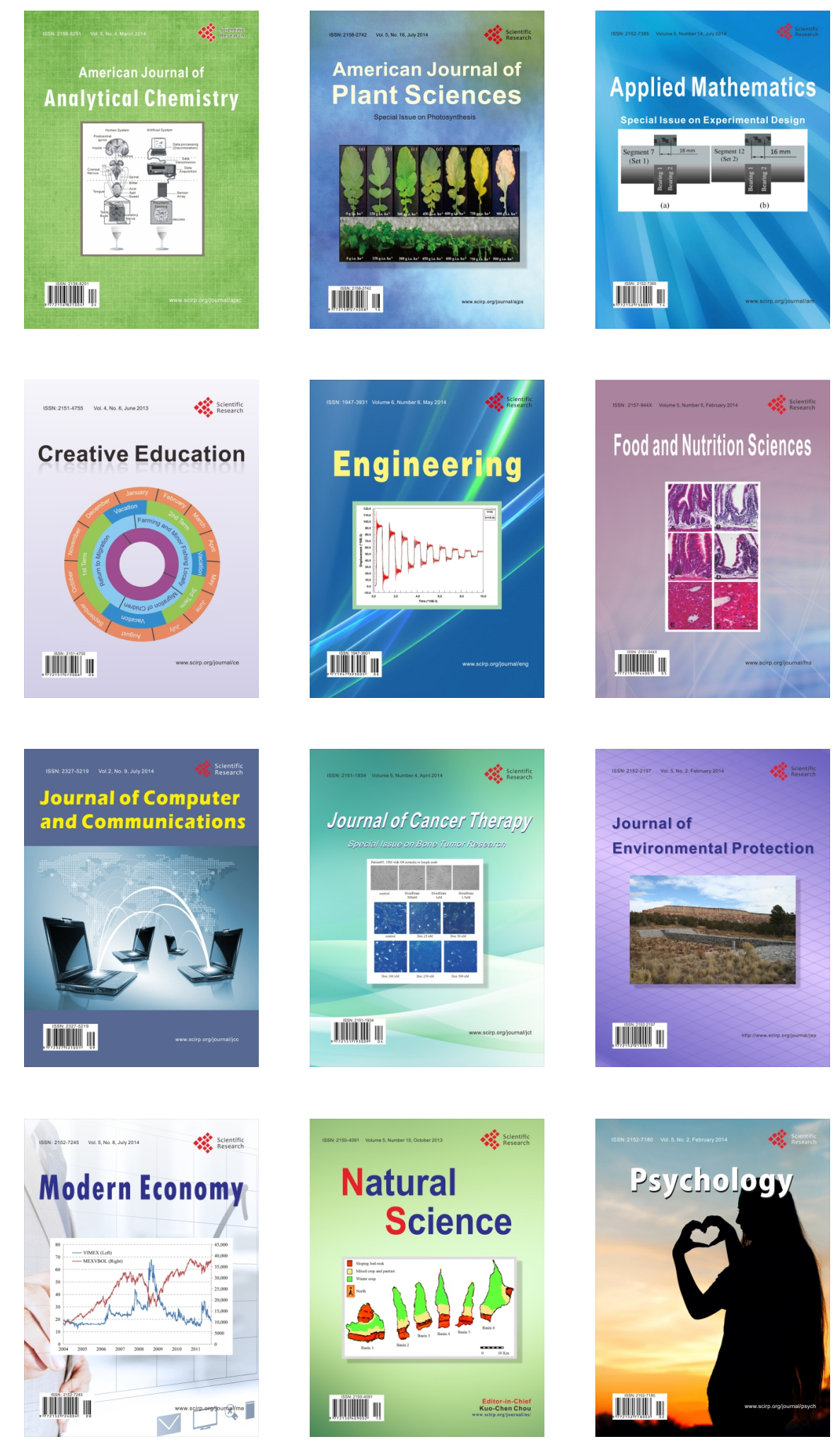